A Journal of Culture, English Language, Teaching \& Literature ISSN 1412-3320 (Print), ISSN 2502-4914(Online)

Vol. 16 No. 2; December 2016

Copyright @ Soegijapranata Catholic University, Indonesia

\title{
BEYOND ABSURDITY: CHARACTER REINFORCEMENT IN BAKDI SOEMANTO'S SHORT STORIES
}

\section{Novita Dewi}

The Graduate Program in Language Studies, Sanata Dharma University, Yogyakarta, Indonesia

$\mathrm{Ph}:$

$+6287838622253$

Received: 02-08-2016
Accepted: 23-02-2017
Email:

ceylandee@gmail.com

Published: 28-02-2017 


\title{
BEYOND ABSURDITY: CHARACTER REINFORCEMENT IN BAKDI SOEMANTO'S SHORT STORIES ${ }^{1}$
}

\author{
Novita Dewi \\ novitadewi@usd.ac.id \\ The Graduate Programme in English Language Studies, \\ Sanata Dharma University, Yogyakarta, Indonesia
}

\begin{abstract}
This article examines the absurd characters in Bakdi Soemanto's selected short stories in the light of character reinforcement. Through the use of analogy of name, environment, and interlocking relationships among the characters, it is revealed that these characters reflect contemporary society's aspirations and expectation of their exemplary leaders or individuals with high authority. The presence of such weird but wise characters discloses the blurred boundaries of sanity and insanity in striving for meaningful life as well as the meaning of life.
\end{abstract}

Key words: Absurdity, character reinforcement, analogy

\begin{abstract}
Abstrak: Artikel ini membahas penokohan dalam sejumlah cerpen Bakdi Soemanto melalui teknik penguatan tokoh. Ketika tokoh-tokoh ini dinalisis melalui analogi nama, analogi lanskap dan analogi antar tokoh, terkuaklah harapan masyarakat zaman sekarang terhadap perilaku ideal pemimpin atau tokoh masyarakat. Kehadiran tokoh yang absurd namun bijak ini mengaburkan batas antara yang waras dan yang tidak dalam pencarian mereka atas makna kehidupan.
\end{abstract}

Kata kunci: absurditas, penguatan tokoh, analogi

\footnotetext{
${ }^{1}$ This article is a further elaboration of the preliminary findings appeared earlier as The quest of life meaning in Bakdi Soemanto's selected short stories" in English Language Studies Indonesia: For Truth and Meaning (Yogyakarta: Sanata Dharma University Press, 2015, pp. 127$135)$ and the Indonesian version thereof Yang absurd, yang arif: Analisis tokoh-tokoh cerpen Bakdi Soemanto. Jurnal Ilmiah Kebudayaan SINTESIS 9, 1 (Maret 2015), pp. 16 - 23.
} 


\section{INTRODUCTION}

This article is written to examine the ways in which characters are designed in Bakdi Soemanto's s selected short stories that appeared in The Magician: A Collection of Short Stories (2001) and Tart di Bulan Hujan (2014). The first collection includes stories written originally in English and translated from Indonesian, some by the writer himself. Published thirteen years later, the second book comprises of 25 stories in Indonesian, some of which had been published in the Sunday edition of the Indonesian daily newspaper Kompas. Initial readings of both books may lead the reader to believe that total chaos prevails in most stories because of the presence of almost all absurd characters. However, the absurd and unreasonable figures may very well satirize people we come across in our daily life regardless of their cultural background and social status. In his introduction to The Magician, Rambadeta aptly says that as ludicrous as the characters are, he is made to "sit back and contemplate on the ordinary citizens' apparent attempt at coping with their day-to-day life struggles" (Soemanto, 2001, p. 6). The discussion is to show that seen through character reinforcement technique, the protagonists in Soemanto's stories are all caught in a moral drama beyond their control. They do not create the drama, but they become unsuspecting actors on a stage set by socio-economic (and political) forces beyond their own capacities to understand.

Absurd characters found in modern play such as Brecht's A Man's a Man (1964), Kafka's The Trial (1972), Sartre's No Exit (1955) (See Milovanovic \& Thomas, 1989, p. 49-50) are hard to forget. Whilst baffled, we take great delight in following the characters' journey throughout the stories. The character does not have to be a benevolent, saint-like and unusually noble figure. Nor is $\mathrm{s} /$ he cast with diabolic cruelty ever known to us to stay in our mind. They are just ordinary people with a degree of absurdity due to their incapability either to resist or to control the conditions imposed upon them. Characters like Vladimir and Estragon who continue to puzzle us with their ludicrousness are particularly interesting to readers of existentialist literature. Norton the insomniac narrator and his alter-ego Tyler Durden in Fight Club are great men whose desire for self-destruction allows us to see the failings of the contemporary politics and commercial culture. To mention other examples still, the characters in Steinback's Of Mice and Man are affected by the shaping conditions of social existence that led them to feel their bitter loneliness and desperation with which the author begs us to rethink of the world we live in (Hart, 2004, p. 35). 
Thus, characters make up an inextricably important part of the literary design as they seize the imagination of the readers. Although the characters are sometimes different in terms of background, interests, physique, outfits, social positions and so forth, they all share our own experiences. They possess things we do not have and wish to have, although the characters' course of action often makes us unease. Simply put, we see (parts of) ourselves in the characters.

\section{LITERATURE REVIEW}

Built on previous techniques of characterization such as those of Chatman, Hamon, Ewen, to mention some, Rimmon-Kenan (1983) expounds indirect characterization in narrative fiction. Despite the development and refinement of narrative theories today as shown by, among others, Nieragden (2002), Rimmon-Kenan's characterization theorizing remains useful. Here, she suggests that indirect characterization can operate through reinforcement of analogy, i.e. analogous names, analogous landscape and analogy between characters. The elaboration is as follows.

Name association is a good clue. Hamon via Rimmon-Kenan (1983, p. 68) mentions that, among others, names often parallel with character trait visually. Letter "o" in a name is often used for the big and fat character, while letter " $\mathrm{i}$ ", is for the small and thin one. Tom and Jerry from the cartoon series and the seafaring Merchant Marine Captain Haddock and his journalist bestfriend Tintin cast by the Belgian cartoonist Hergé in The Adventures of Tintin are but two examples. Note should be taken here that sometimes this visual name association with character portrayal may sometimes work in reverse order. George Milton is a small man with quick-witted brains in Steinbeck's Of Mice and Men. This short-tempered but a loving and devoted man befriends Lennie Small, a huge heavily walking man in contrast to his name. Thus, analogous name can highlight both similarities and contrasts.

Analogy can also operate through onomatopoeic and articulatory names, for example the onomatopoeia of the buzz of flies in the name Beelzebub (Hamon in Rimmon-Kenan, 1983, p. 68). Literally "Lord of the Flies," Baal Zevuv is himself one of Satan's companion arch devils. One can also recall the miser, misanthropic money-lender Ebenezer Scrooge who is cleverly cast by Dickens to create spiteful sound of the very name. The name Dumbledore is reportedly chosen by the author of Harry Potter series from the Early Modern 
English word for "bumblebee", i.e. large hairy bee not only for his physical appearance but also for Dumbledore's own fascination with music and humming to himself. This unique name, matter-of-factly, makes it almost untranslatable given its attached meaning (Wyler, 2003, p. 10). Next, the enigmatic Mrs. Doubtfire of the 1990s American comedy movie continues to delight parents and children alike despite the character's name. Analogous names also include morphological combinations, such as Joseph Carpenter or Sinbad the Sailor, and allegory like the characters in John Bunyan's Pilgrim's Progress which is peopled with Christian, Hopeful, Great-Heart, Envy, Ignorance and many more including the four wicked giants - Giant Grim, Giant Maul, Giant Slay-Good, and Giant Despair.

Next, a writer can be precise, and at times excessive, in describing her/his character by making use of places, buildings, people and environment to be delineated in either narration or dialogue, and sometimes both. Among the famous example is the grave, dark and eerie setting in almost all of Edgar Alan Poe's short stories of the macabre in the likes of "Tell-tale Heart", "The Fall of the House of Usher", "The Cask of Amontilado", "The Black Cat" where we meet morbid, vengeful and death-obsessed characters.

The third analogy is achieved through comparison and contrast of two characters. Like analogous name which can accentuate the similarity and/or difference between the character trait(s) and her/his external make up, the presence of two characters or more in the same story is deemed comparable as to emphasize the respective characterization. Cinderella v. her step-sisters, Cordelia v. Regan and Goneril in Shakespeare's King Lear, Steinbeck's George v. Lennie, are often cited as examples.

Having briefly outlined three main concepts in character reinforcement, this article is to see the extent to which the characters in Bakdi Soemanto's short stories under study can be seen as employment with or without modification of this method. Each character will therefore be examined in the light of character reinforcement through the use of varied correlations in terms of name, environment and intertwining relationships among the characters. To ease the discussion, the section that follows will first present brief summary of each short story. 


\section{PRÉCIS OF THE SHORT STORIES}

In "A Tale of the Magician", instead of looking for a job, Lancingan, to his wife's irritation, keeps on telling everyone about his wistful thinking of becoming a magician. He has nurtured this dream since 35 years ago when a magician came to his kindergarten school to perform numerous spellbinding tricks. From that day on Lancingan wishes no other professions but ability to conjure money and other magical tricks. His search brings him to the old wise man who lives in the Lawu Mountain who soon makes out his visit and hands the magic power to the younger man. Upon the old man's instruction to wash his face and look at the reflection on the water, Lancingan was petrified - his face has completely disappeared. Now that no one can see his face, he can do anything without being recognized, because, says the old man, "Those who are faceless are shameless" (Soemanto, 2001, p. 27)

In "The Barber", the 98 years old Plakotham is a barber whose eighth marriage to Ijah, the dark sweet country girl of 70 years younger, took place after his 90th birthday. Ijah used to be a lotek seller who provided delivery service of her delicious Javanese vegetable salad to Plakotham and later won the heart of the customer. Now that they have been married for 8 years and no sign of pregnancy, Ijah's mother who was in fact the main initiator of this marriage, begins to worry. Besides, money is also scarce because the VIPs who used to see Plakotham for haircut have lately chosen to go to the hair salon instead. Ijah's mother then tells her daughter about Plakotham's mysterious box. Rumour has it that the barber keeps all his wealth inside. On one eventful day when no money is left to buy rice, Ijah waits in suspense to see her husband open the not so heavy a box only to find that inside is the hair of the VIPs treasured by the barber. Ijah is collapsed and barely hears her husband's bragging about the hair to bring to the museum to cash out heaps of money.

Suli the junior clerk in "Eyes" works in a university copying papers and prepares other necessities for the professors. He likes his works and especially feels honoured when the professors sometimes bring gifts from their overseas trips. The only thing that makes Suli discomfort is seeing his friend Subur with his thieving habit. Suli owes Subur a room to stay free of charge, but he cannot stand witnessing Subur brings home reams of paper and tubes of ink. Believing that every action has its own consequences, Suli is determined to expose Subur's crime. He dares to confront Subur who threatens him to poke his eyes out. But then Subur gives Suli a big punch on the stomach and on his way to 
the hospital Suli cries out in pain, "My eyes, Subur ...my eyes, not my innocent stomach...!" (Soemanto, 2001, p. 57)

Like "Eyes", "The Finger" tells of Zowan, an honest IKIP graduate who works as a personnel official, knowing very well that becoming a teacher is not rewarding; And a humiliation at that; What is more when the students come from wealthy families. But unlike Suli in the previous short story, Zowan is not comfortable filling in tax forms of the high-ranking officials with false data. His superior also experiences such nervousness especially when he sees Zowan's deformed left finger which seems always to point towards him and his offense. The superior orders Zowan to have his finger amputated otherwise he will be fired. When the superior visits him after the operation, Zowan is in a deep sleep, but it is the right finger that adamantly stands erect facing the superior "like the burning point of an arrow" (Soemanto, 2001, p. 65). At that instance the superior, imagining fire break cries out loud for help and desperately pleading not guilty with which the hospital shortly turns into chaos.

The I narrator in "Head" is a typist who lately finds that his brain is incapable of synchronizing with his hands. He frequently makes a fool of himself at the recent community security meeting and even at work when he keeps touching the wrong things like drinking from other people's cup, or worse, eating other's half-eaten snack and, worse still, scratching the head of his boss when he's got itchy scalp. Out of the advice of his good friend $\mathrm{Bu}$ Tinny, the narrator takes a leave and has some rests at home. However, things do not work out better after his resignation that he decides to remove his wayward head from the body. When his wife asks the neighbours to help rip the head from his body, he is horrified.

"Foot" is a story of protest. The narrator's feet are always wrapped in socks and covered by shoes. One day the right foot is swollen and any attempts are made in order that it won't hurt when concealed by dress shoes or sport shoes. Problem occurs when the narrator is called to become a Master Ceremony and be fully clothed in Javanese attire including a pair of selop, for slippers with closed toes will make his right foot even more aching. One night the narrator overhears the feet talking to each other: They envy the eyes, the ears, the mouth and other body parts that enjoy the atmosphere and the beautiful girls. Gamelan music and delicious food, whilst feet are kept covered in rubbed and smelly shoes. Upon hearing that, the narrator decides to treat the feet in the same way he takes care of his face, teeth, lips, underarms, etc. fairly and lovingly - some tips he learns from the famous model Lusinem. 
He'll be the first High Javanese speaking (with Solonese dialect) MC in barefoot.

Appeared as "Nyidam" in the Indonesian version, this lighthearted and humorous "Craving" tells of Sri Limbuk, a young pregnant woman who feels queasy every time she smells her husband's body or sees his armpit hair. Burhan can easily meet his wife's request to wash himself four times a day and shave the armpit; but he is unable to discontinue his chicken satay business simply because his wife get nauseous with the smell of the fishy meat. Even when Burhan later prepares the satay and sells the food in the home of his good friend Pak Ambuz, Sri Limbuk is determined to leave him temporarily and stays with her mother. Luckily, thanks to the new venue in front of the museum, Burhan's satay business develops rapidly with more menus including a variety of traditional drinks. Pak Ambuz's nieces offer help as waitresses sporting traditional costumes to pull more customers. Pak Ambuz nonetheless keeps telling Burhan that Sri Limbuk is a very special woman to love who will make him a rich person one day. The now convinced Burhan then braves himself to take his wife back home only to be confronted by his difficult mother-in-law who finally gives in at the sight of a lot of money handed to her. Upon seeing his wife, Burhan offers to buy her golden jewelry and everything she wants, but Sri Limbuk unswervingly rejects because her only wish is to lick unusual objects in the likes of a golf stick, a scale model of a megaproject, and the muffler of a luxurious car. It is not until the pregnant woman unexpectedly breaks wind oozing a rancid stink after two months that she quickly gets up and passionately hugs her husband. She cannot wait to go home with him despite her mother's disapproval. "She's really a special woman", the elated husband thinks to himself (Soemanto, 2001, p. 98; Soemanto, 2014, p.124).

"Tart di Bulan Hujan" is the last work of Bakdi Soemanto (1943 2014) included in the book of the same title. Sum's only wish is to celebrate and enjoy Christmas cake with "si bocah" (meaning "the child") for which reason she is saving her money for months (Soemanto, 2014, p. 145). Despite the objection of her cab driver husband, Sum steadfastly sets aside her wages earned by house cleaning to buy the expensive cake. By the rainy month of December, she has saved enough money to get the decorated, shimmering forest Christmas cake she yearns for so long. Almost immediately after the cake is bought, Sum rushes to the nearby church to put the special-gift-for-the-childcake in front of the crib. The priest declines Sum's idea; and the poor woman brings the cake home with sadness. Sum's husband, much to her surprise, has invited street children to come and kneel around the simple Christmas crib he 
set in their home. Rejoicing, Sum, her husband, and the children sing, laugh, and eat the cake just the same.

\section{DISCUSSION}

The first pattern of character reinforcement in Bakdi Soemanto's short stories discussed are all fighters with funny names. The characters, for the most part, are firmly anchored in daily reality. Almost all of them fight all their life against the hardship of daily living for they are in dire need of financial support. Lancingan is jobless; Plakotham's revenue has dwindled to almost zero; Suli's welfare is under threat and Zowan is soon to lose his job. The I narrators in "Head" and "Foot" are incapable of self-management owing to their respective body organs that refuse cooperation with which their professions are at stake.

Lancingan, Plakotham, Suli and Zowan are unusual names. The author chooses names with some kind of malapropism. Here incorrect, nonsensical and uncommon words are often used in place of a word with a similar sound to create humorous, if not strange, utterance. Whether intended or not, wordplay is clear in the naming of several characters. Suli is a rearrangement of usil (Indonesian word for being nosy) - a name best suit the character (albeit his well-meaning personality) who seems to probe into other people's private affair, in this case, Subur, who steals office supply. When read from back to front and rearranged the word "mahkota" (head or crown in Indonesian) can be grafted from the name Plakotham the barber who provides attentive and meticulous treatment for the the VIPs' hair. To speculate, Zowan is just another Soemanto's many characters with onomatopoeic buzz of a bee such as Pak Zura, Buzz, Bu Zwilly, Zwili Zanten, Pak Ambuz - all depicted in a rather bizarre way. However, it is hard to ignore that the name Zowan is picked out of the author's own fascination with the sound. In speculation, still, the dutiful Zowan obeys his father as well as his superior to have his crooked finger operated. Indonesians with Javanese speaking background often use the word "sowan" or to pay a visit to the older or more reputable person instead of the Indonesian word "berkunjung" to show politeness and deep respect. The same is true with Pak Ambuz who appears briefly in "Craving". As the name conveys, i.e. to sniff, he comes across as undisturbed by fishy smell as to welcome Burhan the satay seller to do his business in his home. 
Name association and sense of smell also appears in "Foot". The narrator in the story reluctantly accepts his emcee job and suggests instead one A. H. Pangambuan to no avail because the committee prefers the Javanesespeaking MC. The Javanese word "ngambu" (to smell something) is inserted in this Bataknese-sounding name. This name resonates the narrator's own swollen smelly right foot. As it stands, the author's skillful choice of names has made character enforcement here effective.

As for the last "human body part" story told by the first person narrator with no name, no clue is apparent, but in "Head" other (minor) characters have analogous names. Morphological combinations appear in the story in such names as Doctor Akar Poteng, Pak Atmo Sate, Pak Karso Ludruk, Pak Sumit Cebol, Professor Utiyoks to show that the narrator mingles with people from all walks of life in the neighbourhood; And to lose his head (read: sanity) is a disgrace. Here we see that all characters find themselves caught in ludicrous situation over which they have no control.

Milovanovic and Thomas argue that characters in existentialist literature are met with the dilemma of choosing between acceptance and resistance (1989, p. 49). By agreeing with unwanted situations, they maintain, the absurd characters promote their own domination. On the contrary, it is by choosing to exercise freedom through resistance that such characters may give meaning both to their existence and their actions even if this path creates disharmony or ill-fated situations. As argued by Kearney, much of the interest in the works of the father of Existentialist novels, Albert Camus, lies on the discord between the character's existence and reality (2013, p.169). Suffice it to say for now that Bakdi Soemanto's short stories often confront the readers with unhappy coincidences that complicate the story, increase the suspense, and, consequently, add greater emotional and comical effects of these stories. That's a moment of absurdity. According to the absurdist, the topsy-turvy world cannot be explained in rational manners. Human beings, thus, need not to add to this chaotic situation, but to focus on and committed to things of importance in this world in order to make life meaningful, if it is true that life is meaningless. The character's apparent irrationality is a major aspect which persists throughout the story.

The second pattern of character reinforcement shown in Bakdi Soemanto's selected short stories is that behind the folly, lies the hero. One might think that these short stories are but reading materials for self-indulgent, sceptic readers who try either to escape or to console themselves with the 
thought that they are not the only one to suffer in this, flawed, world. However, seen from the existentialist point of view, the character's folly articulates the absurdity of all human races. Through the two other types of enforcement, namely analogy of landscape/ setting and analogy between characters, the characters' farcicality sends forth important messages. In fact, it is the folly that comes across as major characteristics of the hero.

To begin with the analogous landscape, the hero is doing unusual things as a result of his concern as well as his conscientious as a sole fighter living in hostile environment. But this well-meaning character is often misunderstood. The barber is prudent; he loves what he does and he does what he loves. His action is absurd but calls for our unswerving commitment to our vocation. Burhan is to choose between his satay business and his wife who cannot stand the smell of sate. Zowan and Suli are by no means successful employees if wealth is the only measure of accomplishment, but they play their conscience in the midst of cheating and corrupt environment. The "master of typist, expert of period and comma" in the short story "Head" is upset when his 8year fine and flawless work is ridiculed by his boss and even advised to see psychology students or doctor for his recently odd behaviour. To quote at length the boss' callous commentary:

Typing [...] is a matter of skill. It's a practical matter. The brain needn't be given too active a role. And even less so all this questioning, reflecting, checking here and there - it's just not necessary. You'll just get yourself all worked up. [...] Typing [...] is not a philosophical matter. It is unrelated to social values, social problems, or any other strange thing like that. Typing is a matter of letters. Nothing more. (Soemanto, 2001, p. 71)

In a society who values instant gratification and devalues hard work, the typist, the junior clerk and the barber to some extent, are not at all popular. Everyone wants to be like Lancingan in "Tale of a Magician" who aspires to cause something to disappear like magic. He wished that nobody would have identified Lancingan (rhymes with "bajingan" the Indonesian word for thug), had he done any crime. Here, the author places the characters among people and places who entirely have different views. For example, husbands who see things differently from the wives; Employees who disagree with their bosses; Husbands controlled by demanding mothers-in-law who want to ensure the better life of their daughters, and many more. As such, the characters do not develop as a product of a specific environment, but an anti-product, hence 
their aberration in the world of the normal. The well-intentioned characters have to live against all odds. Surely, they may not be quite the same as Albert Camus' Sisyphus who keeps on rolling a big rock up to the mountain top only to see it rolling downward again and again. But, it can be argued here that Soemanto's own philosophical stance towards the hero is like that of Steinbeck who believed that "honest and true literature was all about trying to understand human beings- what makes them up and what keeps them going" by means of the bizarre but honorable characters (Hart, 2004: 42). Winet concurs that, Soemanto belongs to the new generation of playwrights/writers who cast existentialist, absurdist and mythicized characters in the life the ordinary people living in contemporary Indonesian society (2010, p. 145). As said elsewhere (Dewi, 2014, p. 113), Soemanto sees human beings in their intense engagement with work as neither terrible penance nor futility, but the meaning of their existence. Behind the absurdity lies the hero.

The last pattern that emerges is the many faces of the fools in Bakdi Soemanto's short stories. Analogy between characters can help illuminate the character traits; And in Bakdi Soemanto's short stories, they come in comparison and contrast. In the magician story, Lancingan is depicted in contrast to his father, his wife and the old man from the Lawu Mountain. Unlike Lancingan, they are all cast as hard workers and scorn Lancingan's wistful thinking. While the barber is thrifty, Ijah and her mother are moneydriven and scheming characters. They unreasonably plot the marriage despite the age difference. Both women share the mother of Sri Limbuk the craving pregnant woman in terms of their contempt of marital commitment in the name of money. Suli is the opposite of Subur. No depiction of him is available in the story but judging from his name, Subur is everything that the skinny Suli is not. Character contrasts are present in the rest of the stories in terms of social status, integrity and, more importantly, the ways they view life itself.

The characters in "Head" and "Foot" are comparable. They both have to go through the time of doubt about their body and self. Just as the character's head is difficult to manage, so are the disobedient feet of the other character, The humorous tone in both stories allows the reader to reflect on one's own ignorance, if not stupidity. How much time do we spend to take care of the unassuming, subordinate part of our body? What does it mean when one member of the body refuses to obey? These are, indeed, not short stories with happy endings, but each offers thought-provoking narration of individuals in search of life-meaning as well as meaningful life. In the end, one might considers that the meaning of life is truly present in the act of searching. 
Meaning exists in the persistent quest. What is painful maybe is not in the eyes of the absurdist. Did not Camus remind us to imagine that Sisyphus is but a happy man?

What can the perseverance of the character in "Tart di Bulan Hujan" be compared with? She works hard to save the money to buy the cake under the scorn of others, only to find that her determination is crushed. Unlike other stories under discussion, Sum's story here is less depressing. Instead, it explores the idea that every person has a special role to play in the divine unfolding at Christmas. Soemanto's fresh take on the Christmas story seems to addresses every person's need for personal meaning during the drizzly, festive season. Presumably, the writer combines the Biblical story of the Magi and Jesus' account of the poor widow who give all their best. The absurdity lies more on the refusal of the priest to accept Sum's idea than the seemingly wasted behavior of our heroine here.

Nevertheless, analogy between characters can be seen between the women in "Craving" and "Tart di Bulan Hujan". Both Sri Limbuk and Sum are strong women who can win (other than defeat) their respective husband's heart. Just as the pregnant woman insists on her husband's hygiene, Sum untiringly convinces her husband that saving for a Christmas gift for "the child" is necessary. Here the two women embody the continual fight for identity and existence, no matter how peculiar their craving for something can be to others.

\section{CONCLUSION}

Bakdi Soemanto's short stories present a redemptive perspective on our oft-mistreatment of weird characters. The absurd characters in the narrative are given voice as they are made to speak to us about what is really happening to them behind their irrationality. The plausibility of the existence of such characters is made through the technique of reinforcement. A number of existentialist ideas, as postulated by Janet Winecoff (1964) for Latin American literature and such later scholars as Maurice Lee (2008) and Richard Brosio (2010), are present in the stories: the severe seclusion of the individual ("Head", "Eyes", "Finger"); the lack of communication among close family members (mildly seen in almost husband-wife relations in the stories discussed); the limit situation or point of crisis in life in which the individual is 
forced to come to grips with reality ("Head", "Eyes", "Finger"), producing anguish and the importance of anguish itself ("Head", "Foot", "A Tale of a Magician", "Tart di Bulan Hujan"); personal authenticity (almost in all stories) or falsification (especially in "A Tale of a Magician" and "The Barber").

Soemanto's short stories provoke us with ill-fated ventures that sometimes make the story far from simple. They increase the readers' suspense as to heighten greater emotional and comic effects. Absurdity of this kind may appeal to some acquired taste, but the short stories discussed can be seen as a means of containment for the society's aspiration today. The presence of the characters may reflect contemporary society's qualms and ordinary people's expectations of their leaders' behaviour - be they government officials, managers, university professors, religious leaders or anyone with high authority. As the characters grow out of their "weird" experiences, we are invited to join them in confronting moral issues while chasing their own dreams that might be absurd to us. Thus, the characterization is so designed to help reveal the blurred boundaries of sanity and insanity in striving for life meaning as well as meaning of life. To sum up, Bakdi Soemanto offered us stories with absurd characters to help us rethinking of the world we live in.

\section{REFERENCES}

Brosio, R. A. (2000). Chapter Five: Existentialist Contingency, We May Just Be On Our Own-And Camus's Solidarity. In Counterpoints, 75, 161-194.

Dewi, N. (2014). Sajak-sajak Sahabat Sadhar: Sebuah Apresiasi Puisi. Yogyakarta: Penerbit Universitas Sanata Dharma.

Dewi, N. (2015). Yang absurd, yang arif: analisis tokoh-tokoh cerpen Bakdi Soemanto. In Jurnal Ilmiah Kebudayaan SINTESIS, 9 (1), Maret, 16 - 23.

Dewi, N. (2015). The quest of life meaning in Bakdi Soemanto's selected short stories. In N. Dewi \& B. Bram (Eds.), English Language Studies Indonesia: For Truth and Meaning, 127-135. Yogyakarta: Sanata Dharma University Press.

Hart, R. E. (2004). Moral experience in Of Mice and Men: Challenges and reflection. The Steinbeck Review, 1 (2), Fall, 31-44. Stable URL: http://www.jstor. org/stable/41583611 
176 Celt, Volume 16, Number 2, December 2016, pp. 163-176

Kearney, P. (2013). Absurdism and lyricism: Stylistic extremes in Camus' novels. Journal of Camus Studies.

Lee, M. (2008). Pessimism and existentialism in V.S. Naipaul. Journal of Caribbean Literatures, 5, (2), Spring, 153-167. Stable URL: http://www.jstor. org/stable/40986260

Milovanovic, D. \& Thomas, J. (1989). Overcoming the absurd: prisoner litigation as primitive rebellion. Social Problems 36, (1), February, 48-60. Stable URL: http://links.jstor.org/sici?sici=0037-7791\%28198902 \%2936\%3A1\%3C48\%3AOTAPLA\%3E2.0.CO\%3B2-3.

Nieragden, G. (2002). Focalization and narration: Theoretical and terminological refinements. Poetics Today, 23 (4), 685-697.

Rimmon-Kenan, S. (1994). Narrative Fiction: Contemporary Poetics. London: Routledge.

Soemanto, B. (2001). The Magician: A Collection of Short Stories. Yogyakarta: Kanisius.

Soemanto, B. (2014). Tart di Bulan Hujan: Kumpulan Cerpen Kompas. Jakarta: Penerbit Buku Kompas.

Winecoff, J. (1964). Existentialism in the novels of Elena Soriano. In Hispania, 47 (2), May) 309-315. Stable URL: http://www.jstor.org/ stable/336667

Winet, E. D. (2010). Hamlet and Caligula: Echoes of a Voice Unclear in Origins. In Indonesian Postcolonial Theatre (pp. 141-173). Palgrave Macmillan UK.

Wyler, L. (2003). Harry Potter for children, teenagers and adults. Meta: Journal des traducteursMeta:/Translators' Journal, 48 (1-2), 5-14. 